\title{
吸着効果を受ける微速浸透流に関する実験的研究 \\ EXPERIMENTAL STUDY ON THE ABSORBED WATER FOR MICRO-SEEPAGE
}

\section{1. まえがき}

粘土,シルトのごとき微粒土中のレイノルズ数が小さ い浸透流，いわゆる微速浸透流に打いて，流れはダル シー流とはまったく異なった機構をもつ。

その理由の一つに, 微粒土中の水の挙動は, 砂, 砂利 などの粗粒土中の水のそれと物理的性質が非常に異なっ ているということがあげられる。

すなわち, 微粒土の空げき中の水は分子密度が高く, 土粒表面に㧊いて吸着力を受け, 流動によって大きい粘 性を示す。

この特異現象は, 水分子自体が極性を有し, 土粒表面 一吸着される, いわゆる吸着効果に起因するが, 浸透流 を考える場合のみならず, 土の力学的性質を吟味する際 もこの吸着水の物理的, 化学的性質を十分知る必要があ る。

最近, 非ダルシー流としてダルシー則の妥当性の吟味 に関連し微速浸透流の研究がなされているが，現象その もののメカニズムがわかっていない。

筆者らは吸着水の流れにおよぼす影響について，従来 行なわれた透水実験のみでは十分でないと考え，水以外 の物理, 化学的特性のわかった流体 (メチルアルコー ル，ベンゼン）で浸透実験を行ない，浸透流をそれら流 体特性と対比しながら基磷的に研究する。

\section{2. 微速漫透流の特異性}

まず, 問題点を明確にするため, 微速浸透流における 流れの特性をのべ, 従来の研究成果について若干ふれ る。

F.H. King $(1898)^{1)}$ は真ちゅう線網, 細砂, 砂岩を

* 正会員 工修 大阪府立工業高等専門学校助教授 土木工学科

** 正会員 工博 大阪大学教授 工学部土木工学科
佐 藤 邦 明*・室田明**

By. Kuniaki Sato and Akira Murota

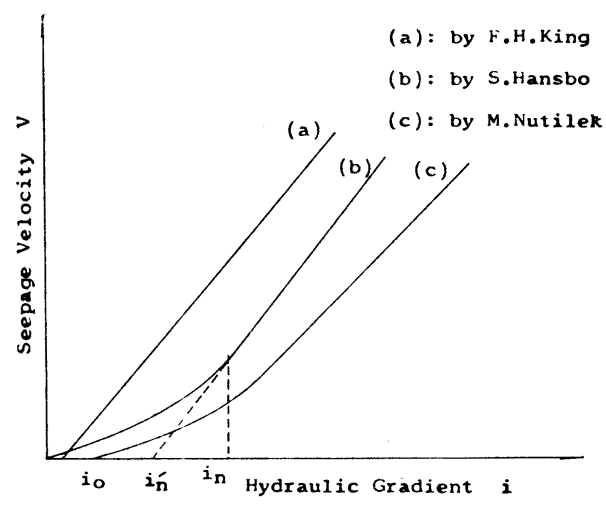

図一1 見掛けの流速と動水勾配の実験的関係

用いて綿密な透水実験を行ない，見掛けの流速 vと動 水勾配 $i$ の関倸について, 図一1 の（a）のような結果 を得た。

その結果は, $i$ が小さい場合, ダルシー則が成立しな いことを示している。つまり, $i$ がある一定值, 始動動 水勾配 (threshold hydraulic gradient) $i_{0}$ 亿達しなけ

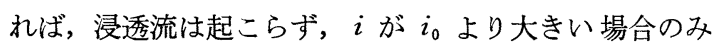
$v \sim i$ 関係は線型的変化をするというものである。

しかし, この実験で用いられた多孔体は粘土, シルト に比べれば, 空げき規模は大きいといえる。

次に, 粘土のような微粒土の場合については, S. Hansbo $(1960)^{2)}$ が粘土の透水実験で 図一1の (b) のご とき実測を得た。King の実測結果とまったく異なり, $v \sim i$ 関係は, $i$ の増加に従い $v$ が非線型的に変化し, ある動水勾配 $i_{n}$ をこえて, 両者の関係が線型的である といらことになる。

さらに, M. Kutilek $(1967)^{3)}$ によれば, 同じく粘土 の場合, 図一1の (c) の上らな実測結果が得られてい る。浸透流は始動動水勾配 $i_{0}$ 亿達するまで起こらない が， $i_{0}$ より大きい $i$ について $v \sim i$ 関係は Hansbo の 結果とほぼ同様な変化をする。 
以上，三つの代表的な実測結果について概略説明した が，これらの事実を要約すれば次のようにいえる。

透水試験によって細砂のごとき細粒土の $v \sim i$ 関係は 始動動水勾配を考えれば，線型的変化をする。また，粘 土のごとき微粒土の $v \sim i$ 関係は非線型的変化をする が，始動動水勾配の認められる場合と認められない場合 がある。

従来，この $v \sim i$ 関倸を説明するためのアプローチ は, レオロジ一的, あるいは流体力学的立場からなされ ている。

まず，レオロジ一的立場から Buckingham-Reiner ${ }^{4}$ の式と呼ばれるものがある。

$$
v=\frac{r_{0}{ }^{2} \rho g}{8 \mu} i\left[1-\frac{4}{3} \frac{i_{0}}{i}+\frac{1}{3}\left(\frac{i_{0}}{i}\right)^{4}\right] .
$$

ここで, $\mu$ : 流体の分子粘性係数, $\rho$ : 密度, $g$ : 重力 の加速度, $r_{0}$ : 空げきと等価な断面積芏もつ細管の半 径, $i_{0}$ : 始動動水勾配である。

この式は細管中のビンガム流動，いわゆる栓流（plug flow）から導入されたもので，v〜i曲線は図一1の (c) 曲線と同様の関係をもつ。

また，この（c）曲線と類似の関係を表わすものとし て, Swartzendruber の経験式 ${ }^{5)}$ が知られている。

$$
v=B\left\{i-J\left(1-e^{-C_{0} i_{0}}\right)\right\}
$$

ここで， $B, J, C_{0}$ は実験的に決まる倸数である。

この式は微速浸透流を非ニュートン流動と考えて導入 されたものである。

さらに, Hansbo ${ }^{6)}$ は

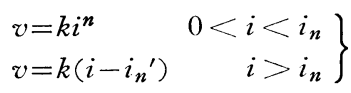

ここで, $k$ : 透水係数, $n:$ 土質, 空げき率, 温度によ って決まる指数, $i_{n}$ : 非線型一線型変化移行動水勾配で ある。

この式は 図一1の (b) と同様の関係を与える。

次に, 流体力学的立場から, 佐藤 ${ }^{7)}$ は吸着粘性の概念 を導入し, 理論的に微速浸透流を論じた。浸透流場内の 粘性の見掛け上の増大, 空げき中の流速分布, せん断力 分布を的確に説明でき，抵抗係数の導入をあわせ，流れ のメカニズムを的確に知ることができる。しかし，この 考え方によって，先に述べた流れのレオロジー的性質を 説明することは不可能である。

微速浸透流の特異性を略述したが， ひ〜 $i$ 関係の実測 事実, さらに, その従来のアプローチを通じて, この種 の浸透流は動水勾配が小さい間はレオロジ一的特性を示 し, 動水勾配が大きくなると流体力学的特性（つまり, ダルシー則を満たす）を示す傾向があるということは銘 記すべきである。

要するに, 微速浸透流はレオロジ一的, 流体力学的特
性をあわせもつと考えられる。

\section{3. 水分子と吸着水}

周知のごとく水分子は水素と酸榇からなり，それぞれ の原子間で単純には共有結合をしている。しかし，多く の他の流体, 気体分子に見られるように, 水分子は分子 自体 (電気的) 極性を有し，電気的に不安定である。

一般に, 水分子は双極性分子 (bi-polar molecule) で あり，図一2 の (a), (b), (c) に示したごとくである。

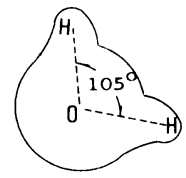

(a)

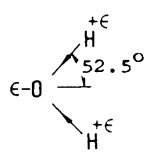

(b)

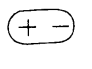

(c)
図一－水分子

図中，（a）は水分子の幾何的形状 ${ }^{8)}$ ，(b) は双極化, (c) は電気的にみた慣習的簡略記号をそれぞれ表わして いる。（b）眓からわかるように, 酸素原子付近が負, 二 つの水素原子付近がともに正に荷電（荷電強度 $\varepsilon$ ) して いる。

通常の水は, 双極性分子, 無極性分子, 双極性と無極 性の中間的分子の集合体と考えられている。

無論, 三者の割合からすれば，無極性分子は少なく, これらの全水分子はある温度, 圧力の下で高速運動して いる。

こういった水分子が正，負いずれかに荷電した固体表 面付近に電気的に吸着されたものが, 通常, 吸着水 (absorbed water) と呼ばれる。

一般に, 粘土, シルトのごとき微粒土の表面は負に荷 電しているといわれているから, その表面に多量の吸着 水を保持していることになる。

当面問題にしている微粒土中の浸透流において，この 吸着水の存在は流れにきわめて重要な影響を与える。こ の吸着水は次のような物理的性質がある。

（1）水分子相互間の引力は土粒子表面付近でもっと も強く, 表面から遠ざかるにつれ減少し, 十分離れたと ころで消失する。

（2）吸着水は上記（1）の強弱によって，土粒子表 面付近の吸湿水層 (hygroscopic water layer) と吸着水 層に分けられる。

（3）吸湿水層内の水は高以告力, 密度, 粘性を顕わ し外力によって流動しない。

（4）吸着水層内の水は通常の水より大きい圧力, 密 度，粘性を有するが，外力によって流動する。 


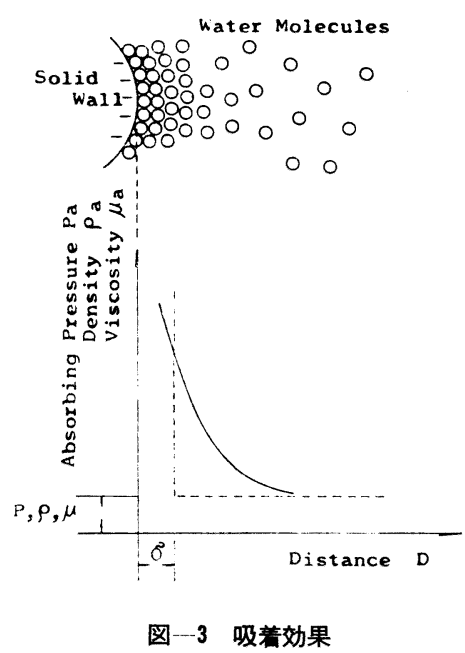

（5）吸着力の強弱, 吸湿, および吸着水層の厚さは ともに微粒土の鉱物成分, 水中の溶解イオンなどに関係 する。

以上の (1)〜 (5) までの事柄を要約すれば，図一3の ようになる。図中, $p_{a}, o_{a}, \mu_{a}$ はそれぞれ吸着効果によ ，て生ずる圧力, 密度, 粘性係数であり, $p, \rho, \mu$ はそ れぞれ, 土粒表面から十分離れたところでの圧力, 密 度, 粘性係数である。さらに, $\delta$ は吸湿水層の厚さであ る。

もちろん, 土粒表面からの距離 $I$ と $p_{a}, \rho_{a}, \mu_{a}$ の 関数関倸が同一の曲線を与えるとは考えられないが, $p_{a}, \rho_{a}, \mu_{a}$ のいずれも距離の $n$ 乗に逆比例して減少す ることは容易に推定できる。また, $\delta$ の值は外力と前記 （5）に関係し，一定の值をもたないが，ほぼ 1/100～1/ 1000 ミクロンと考えられる ${ }^{9}$ 。

\section{4. 浸透実験}

\section{（1）実験装置}

奉験装置の概略が図一4に示されている。

その主要部は図中の (1)〜 (7) である。この装置は通 常の定水位透水試験装置と同じであり, 試験方法も同様 である。ただし，揮発性流体を用いるため，浸透流量の 揮発性, さらに浸透流量が小さいため, 流出部の越流面 の安定性の二点で配慮が加えられている。

順次説明すると, まず，(1) はオーバフロ一用直立管 (長さ $9.0 \mathrm{~cm}$, 内径 $2.0 \mathrm{~cm}$, 真ち吅製), (2) は整流 貯留部 (長さ $5.5 \mathrm{~cm}$, 内径 $6.0 \mathrm{~cm}$, 真ちゅう製), (3) は土試料充填円筒（長さ $16 \mathrm{~cm}$, 内径 $7 \mathrm{~cm}$, ガラス製)， (4) 整流貯留部 (長さ $5.5 \mathrm{~cm}$, 内径 $6.0 \mathrm{~cm}$, 真ちゅう 製)，(5) オーバフロー槽（内寸 $10 \times 9 \times 6 \mathrm{~cm}$, 鋼鉄製)，

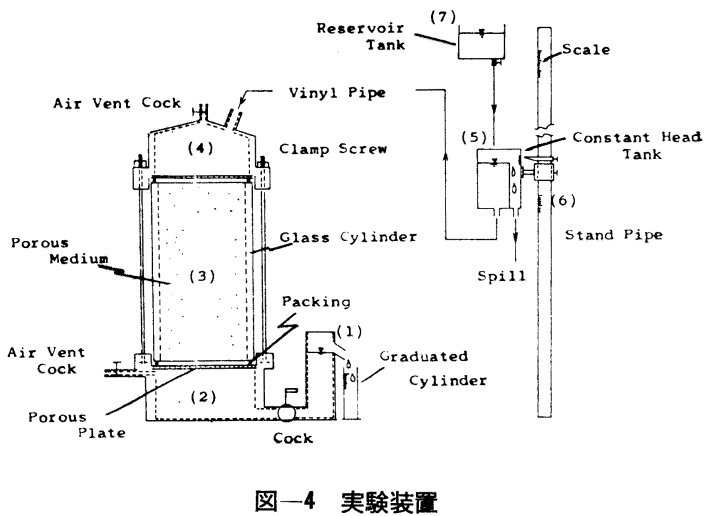

（6）スタンドパイプ（寸法 $2.5 \times 2.5 \times 75 \mathrm{~cm}$, 真ちゅう 製), (7) 貯留ビ一力 (高さ $15.0 \mathrm{~cm}$, 内径 $10.0 \mathrm{~cm}$, ガ ラス製) である。なお, 試験器とオーバフロ一槽を連結 するものは内径 $0.8 \mathrm{~cm}$ のビニールパイプである。

実験方法は定水位透水試験の場合とまったく同じであ るため省略する。

\section{(2) 土試 料}

土試料は 図一5にその粒径加積曲線を示した三種であ る。それぞれの試料は土の三角座標による分類からすれ ば, 粘土, シルト質粘土, 細砂である。ここで, 粘土は 市販されている笠岡粘土 (褐色), また, シルト質粘土 は大阪市内の地下鉄工事現場から採取したもので黒色で ある。さらに, 細砂は市販のものである。

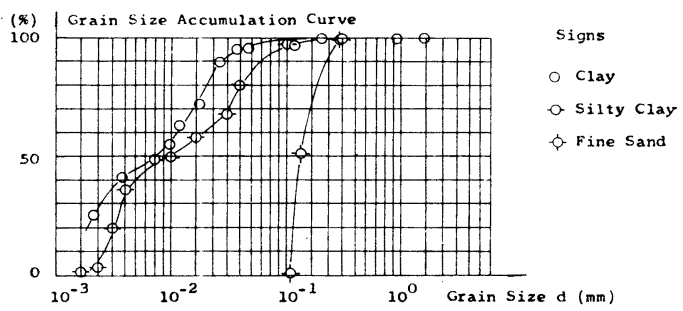

\section{図一5 土試料の粒径加積曲線}

平均粒径 $d_{m}$ は, 粘土 $d_{m}=0.002 \mathrm{~cm}$, シルト $d_{m}=$ $0.0031 \mathrm{~cm}$, 細砂 $d_{m}=0.032 \mathrm{~cm}$ である。また, 土試料 の比重, 実験時の空げき率については表一1に一括して 掲げてある。

\section{（3）浸透流体}

実験に用いられた流体は水, メチルアルコール（メ夕 ノール) $\mathrm{CH}_{3} \mathrm{OH}$, ベンゼン $\mathrm{C}_{6} \mathrm{H}_{6}$ である。

水は普通の水道水であり, チルアルコールは純度 99.5\%, ベンゼンは純度 $90 \%$ 以上で, 市販のものであ る。なお, 実験流体の特性は実験時の温度で表一1 に示 されている。 
表一1 流体特性と多孔体特性

\begin{tabular}{|c|c|c|c|c|}
\hline & & 粘 土 & ンルト質粘土 & 細砂 \\
\hline 水 & $\begin{array}{c}T \\
r \\
\lambda \\
d_{m} \\
\rho \\
\nu\end{array}$ & $\begin{array}{l}11.0 \\
2.63 \\
46.2 \\
0.002 \\
0.9996 \\
0.0127\end{array}$ & $\begin{array}{l}16.0 \\
2.708 \\
44.3 \\
0.0031 \\
0.9987 \\
0.0112\end{array}$ & $\begin{array}{c}15.0 \\
2.65 \\
38.2 \\
0.032 \\
0.9991 \\
0.0115\end{array}$ \\
\hline 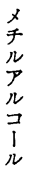 & $\begin{array}{c}T \\
r \\
\lambda \\
d_{m} \\
\rho \\
\nu\end{array}$ & $\begin{array}{l}13.0 \\
2.63 \\
46.2 \\
0.002 \\
0.813 \\
0.0075\end{array}$ & $\begin{array}{l}14.0 \\
2.708 \\
44.3 \\
0.0031 \\
0.812 \\
0.0075\end{array}$ & $\begin{array}{c}12.0 \\
2.65 \\
38.2 \\
0.032 \\
0.814 \\
0.0074\end{array}$ \\
\hline $\begin{array}{l}\text { ベ } \\
\text { ン } \\
\text { せ } \\
\text { ン }\end{array}$ & $\begin{array}{c}T \\
\gamma \\
\lambda \\
d_{m} \\
\rho \\
\nu\end{array}$ & $\begin{array}{l}11.0 \\
2.63 \\
46.2 \\
0.002 \\
0.88 \\
0.0078\end{array}$ & $\begin{array}{l}11.0 \\
2.708 \\
44.3 \\
0.0031 \\
0.88 \\
0.0078\end{array}$ & $\begin{array}{l}11.0 \\
2.65 \\
38.2 \\
0.032 \\
0.88 \\
0.0078\end{array}$ \\
\hline
\end{tabular}

$T$ : 液温 $\left({ }^{\circ} \mathrm{C}\right), r:$ 土の真比重, $\lambda:$ 空げき率, $d_{m}:$ 平均粒径 $(\mathrm{cm})$, $\varphi:$ 流体密度 $\left(\mathrm{g} / \mathrm{cm}^{3}\right), \nu$ : 流体の動粘性係数 $\left(\mathrm{cm}^{2} / \mathrm{sec}\right)$ (流体特性: 水工学便覧による) ${ }^{10}$

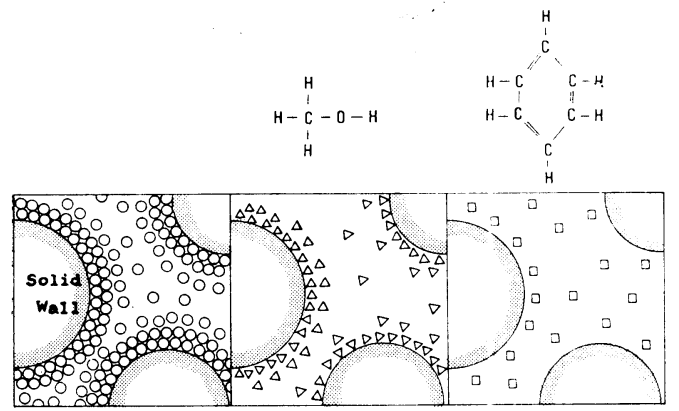

(a) 0 water

(b) Methyl Alcohol (c) $\square$ Benzene

\section{図一6 流場想定図}

よく知られているように，メチルアルコール，および ベンゼンの化学構造式は図一6 に示したもので, メチル アルコールは弱い（電気的）極性を有し，ベンゼンは無 極性分子である。

したがって，これら三種の流体で浸透実験を行なった 場合, 微粒土中の空げき内部での流場はミク口的に図一 6 に示したようになると考えられる。

つまり，図中（a）のように，水分子は土粒子表面に 吸着され, 流水断面積を減少させ, 流場内の粘性は高く なる。しかし，メチルアルコールの場合，（b）のように 吸着作用は弱く，水ほど吸着粘性は顕われない。ベンゼ ンの場合，(c) のごとく無極性分子であるため吸着はま ったく起こらず, 吸着効果は考えられない。したがっ て，ベンゼンによる浸透実験の結果，吸着効果をまった く受けない流れを再現することができ，水による透水試 験結果と照合し, 吸着水の特性を把握することができ る。

\section{5. 実測 結果}

粘土, シルト質粘土, 細砂の浸透実験結果がそれぞ れ, 見掛けの流速 $v$, 浸透係数 $k$, レイノルズ数 $R_{e}$, 抵 抗係数 $\zeta$ について 表一2〜4 に掲げられている。なお， 表中のレイノルズ数, 抵抗係数の表現は最もしばしば用 いられる

\section{表一2 粘土の漫透実験結果}

\begin{tabular}{|c|c|c|c|c|c|}
\hline & $i$ & $v(\mathrm{~cm} / \mathrm{sec})$ & $k(\mathrm{~cm} / \mathrm{sec})$ & $R_{e}$ & $\zeta$ \\
\hline \multirow{6}{*}{ 水 } & 1.250 & $3.530 \times 10^{-8}$ & $2.824 \times 10^{-8}$ & $5.764 \times 10^{-9}$ & $3.932 \times 10^{15}$ \\
\hline & 1.875 & $3.236 \times 10^{-7}$ & $1.726 \times 10^{-7}$ & $5.284 \times 10^{-8}$ & $7.019 \times 10^{13}$ \\
\hline & 3.125 & $6.496 \times 10^{-7}$ & $2.079 \times 10^{-7}$ & $1.061 \times 10^{-7}$ & $2.903 \times 10^{13}$ \\
\hline & 4.375 & $4.511 \times 10^{-6}$ & $1.031 \times 10^{-6}$ & $7.366 \times 10^{-7}$ & $8.428 \times 10^{11}$ \\
\hline & 6.250 & $6.857 \times 10^{-6}$ & $1.097 \times 10^{-6}$ & $1.120 \times 10^{-6}$ & $5.211 \times 10^{11}$ \\
\hline & 15.000 & $1.715 \times 10^{-5}$ & $1.143 \times 10^{-6}$ & $2.800 \times 10^{-6}$ & $2.000 \times 10^{11}$ \\
\hline \multirow{8}{*}{$\begin{array}{l}\not x \\
\text { f } \\
ル \\
P \\
ル \\
\vec{J} \\
\text { I } \\
ル\end{array}$} & 0.625 & $1.291 \times 10^{-5}$ & $2.066 \times 10^{-5}$ & $3.344 \times 10^{-6}$ & $1.470 \times 10^{10}$ \\
\hline & 1.250 & $3.322 \times 10^{-5}$ & $2.658 \times 10^{-5}$ & $8.604 \times 10^{-6}$ & $4.438 \times 10^{9}$ \\
\hline & 1.875 & $6.195 \times 10^{-5}$ & $3.304 \times 10^{-5}$ & $1.605 \times 10^{-5}$ & $1.915 \times 10^{9}$ \\
\hline & 2.500 & $8.776 \times 10^{-5}$ & $3.510 \times 10^{-5}$ & $2.273 \times 10^{-5}$ & $1.272 \times 10^{9}$ \\
\hline & 3.125 & $1.079 \times 10^{-4}$ & $3.453 \times 10^{-5}$ & $2.795 \times 10^{-5}$ & $1.052 \times 10^{9}$ \\
\hline & 3.750 & $1.312 \times 10^{-4}$ & $3.499 \times 10^{-5}$ & $3.399 \times 10^{-5}$ & $8.537 \times 10^{8}$ \\
\hline & 4.375 & $1.562 \times 10^{-4}$ & $3.570 \times 10^{-5}$ & $4.045 \times 10^{-5}$ & $7.029 \times 10^{8}$ \\
\hline & 6.563 & $2.584 \times 10^{-4}$ & $3.937 \times 10^{-5}$ & $6.693 \times 10^{-5}$ & $3.853 \times 10^{8}$ \\
\hline \multirow{3}{*}{$\ddot{\sim}$} & 0.625 & $8.488 \times 10^{-5}$ & $1.358 \times 10^{-4}$ & $2.156 \times 10^{-5}$ & $3.400 \times 10^{8}$ \\
\hline & 1.250 & $1.576 \times 10^{-4}$ & $1.261 \times 10^{-4}$ & $4.004 \times 10^{-5}$ & $1.972 \times 10^{8}$ \\
\hline & 1.875 & $2.526 \times 10^{-4}$ & $1.347 \times 10^{-4}$ & $6.417 \times 10^{-5}$ & $1.152 \times 10^{8}$ \\
\hline ン & 2.500 & $3.537 \times 10^{-4}$ & $1.415 \times 10^{-4}$ & $8.983 \times 10^{-5}$ & $7.834 \times 10^{7}$ \\
\hline ゼ & 3.125 & $4.515 \times 10^{-4}$ & $1.445 \times 10^{-4}$ & $1.147 \times 10^{-4}$ & $6.008 \times 10^{7}$ \\
\hline \multirow{3}{*}{ ン } & 3.750 & $5.305 \times 10^{-4}$ & $1.415 \times 10^{-4}$ & $1.347 \times 10^{-4}$ & $5.224 \times 10^{7}$ \\
\hline & 4.375 & $6.388 \times 10^{-4}$ & $1.460 \times 10^{-4}$ & $1.623 \times 10^{-4}$ & $4.203 \times 10^{7}$ \\
\hline & 6.563 & $9.787 \times 10^{-4}$ & $1.491 \times 10^{-4}$ & $2.486 \times 10^{-4}$ & $2.686 \times 10^{7}$ \\
\hline
\end{tabular}

表一3 シルト筫粘土の浸透実験結果

\begin{tabular}{|c|c|c|c|c|c|}
\hline & $i$ & $v(\mathrm{~cm} / \mathrm{sec})$ & $k(\mathrm{~cm} / \mathrm{sec})$ & $R_{e}$ & 5 \\
\hline \multirow{8}{*}{ 水 } & 0.625 & $1.804 \times 10^{-6}$ & $2.886 \times 10^{-6}$ & $4.817 \times 10^{-7}$ & $1.167 \times 10^{12}$ \\
\hline & 1.250 & $3.299 \times 10^{-6}$ & $2.639 \times 10^{-6}$ & $8.808 \times 10^{-7}$ & $6.981 \times 10^{11}$ \\
\hline & 1.875 & $1.074 \times 10^{-5}$ & $5.728 \times 10^{-6}$ & $2.868 \times 10^{-6}$ & $9.881 \times 10^{10}$ \\
\hline & 2.500 & $2.512 \times 10^{-5}$ & $1.005 \times 10^{-6}$ & $6.707 \times 10^{-6}$ & $2.407 \times 10^{10}$ \\
\hline & 3.125 & $2.806 \times 10^{-5}$ & $8.979 \times 10^{-6}$ & $7.492 \times 10^{-6}$ & $2.411 \times 10^{10}$ \\
\hline & 3.750 & $3.753 \times 10^{-5}$ & $1.001 \times 10^{-5}$ & $1.002 \times 10^{-5}$ & $1.617 \times 10^{10}$ \\
\hline & 4.375 & $4.677 \times 10^{-5}$ & $1.069 \times 10^{-5}$ & $1.249 \times 10^{-5}$ & $1.215 \times 10^{10}$ \\
\hline & 6.563 & $7.146 \times 10^{-5}$ & $1.089 \times 10^{-5}$ & $1.908 \times 10^{-5}$ & $7.808 \times 10^{9}$ \\
\hline \multirow{8}{*}{$\begin{array}{l}\not \\
\text { f } \\
ル \\
P \\
ル \\
ב \\
1 \\
ル\end{array}$} & 0.625 & $1.353 \times 10^{-5}$ & $2.165 \times 10^{-5}$ & $5.534 \times 10^{-6}$ & $2.074 \times 10^{10}$ \\
\hline & 1.250 & $4.872 \times 10^{-5}$ & $3.898 \times 10^{-5}$ & $1.993 \times 10^{-5}$ & $3.199 \times 10^{9}$ \\
\hline & 1.875 & $7.507 \times 10^{-5}$ & $4.004 \times 10^{-5}$ & $3.070 \times 10^{-5}$ & $2.021 \times 10^{9}$ \\
\hline & 2.500 & $1.126 \times 10^{-5}$ & $4.504 \times 10^{-5}$ & $4.605 \times 10^{-5}$ & $1.198 \times 10^{9}$ \\
\hline & 3.125 & $1.405 \times 10^{-4}$ & $4.496 \times 10^{-5}$ & $5.746 \times 10^{-5}$ & $9.619 \times 10^{8}$ \\
\hline & 3.750 & $1.732 \times 10^{-4}$ & $4.619 \times 10^{-5}$ & $7.084 \times 10^{-5}$ & $7.595 \times 10^{8}$ \\
\hline & 4.375 & $1.970 \times 10^{-4}$ & $4.503 \times 10^{-5}$ & $8.057 \times 10^{-5}$ & $6.850 \times 10^{8}$ \\
\hline & 6.563 & $3.176 \times 10^{-4}$ & $4.839 \times 10^{-5}$ & $1.299 \times 10^{-4}$ & $3.952 \times 10^{8}$ \\
\hline \multirow{3}{*}{$\dot{\sim}$} & 0.625 & $1.334 \times 10^{-4}$ & $2.134 \times 10^{-4}$ & $5.243 \times 10^{-5}$ & $2.134 \times 10^{8}$ \\
\hline & 1.250 & $2.613 \times 10^{-4}$ & $2.090 \times 10^{-4}$ & $1.027 \times 10^{-4}$ & $1.112 \times 10^{8}$ \\
\hline & 1.875 & $3.825 \times 10^{-4}$ & $2.040 \times 10^{-4}$ & $1.503 \times 10^{-4}$ & $7.787 \times 10^{7}$ \\
\hline ン & 2.500 & $5.305 \times 10^{-4}$ & $2.122 \times 10^{-4}$ & $2.085 \times 10^{-4}$ & $5.398 \times 10^{7}$ \\
\hline \multirow[t]{2}{*}{ ゼ } & 3.125 & $6.756 \times 10^{-4}$ & $2.162 \times 10^{-4}$ & $2.655 \times 10^{-4}$ & $4.160 \times 10^{7}$ \\
\hline & 3.750 & $7.795 \times 10^{-4}$ & $2.079 \times 10^{-4}$ & $3.063 \times 10^{-4}$ & $3.750 \times 10^{7}$ \\
\hline \multirow[t]{2}{*}{ ン } & 4.375 & $9.311 \times 10^{-4}$ & $2.128 \times 10^{-4}$ & $3.659 \times 10^{-4}$ & $3.066 \times 10^{7}$ \\
\hline & 6.563 & $1.386 \times 10^{-3}$ & $2.112 \times 10^{-4}$ & $5.447 \times 10^{-4}$ & $2.076 \times 10^{7}$ \\
\hline
\end{tabular}




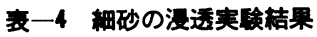

\begin{tabular}{|c|c|c|c|c|c|}
\hline & $i$ & $v(\mathrm{~cm} / \mathrm{sec})$ & $k(\mathrm{~cm} / \mathrm{sec})$ & $\boldsymbol{R}_{\boldsymbol{e}}$ & 6 \\
\hline \multirow{9}{*}{ 水 } & 0.313 & $7.150 \times 10^{-3}$ & $2.284 \times 10^{-2}$ & $1.868 \times 10^{-2}$ & $3.842 \times 10^{5}$ \\
\hline & 0.625 & $1.364 \times 10^{-2}$ & $2.182 \times 10^{-2}$ & $3.563 \times 10^{-2}$ & $2.108 \times 10^{5}$ \\
\hline & 1.250 & $2.546 \times 10^{-2}$ & $2.037 \times 10^{-2}$ & $6.650 \times 10^{-2}$ & $1.210 \times 10^{5}$ \\
\hline & 1.875 & $3.655 \times 10^{-2}$ & $1.949 \times 10^{-2}$ & $9.547 \times 10^{-2}$ & $8.802 \times 10^{4}$ \\
\hline & 2.500 & $4.885 \times 10^{-2}$ & $1.954 \times 10^{-2}$ & $1.276 \times 10^{-1}$ & $6.572 \times 10^{4}$ \\
\hline & 3.125 & $5.976 \times 10^{-2}$ & $1.912 \times 10^{-2}$ & $1.561 \times 10^{-1}$ & $5.489 \times 10^{4}$ \\
\hline & 3.750 & $6.860 \times 10^{-2}$ & $1.829 \times 10^{-2}$ & $1.792 \times 10^{-1}$ & $4.998 \times 10^{4}$ \\
\hline & 4.375 & $7.968 \times 10^{-2}$ & $1.821 \times 10^{-2}$ & $2.081 \times 10^{-1}$ & $4.322 \times 10^{4}$ \\
\hline & 6.563 & $1.182 \times 10^{-1}$ & $1.801 \times 10^{-2}$ & $3.088 \times 10^{-1}$ & $2.944 \times 10^{4}$ \\
\hline \multirow{8}{*}{ 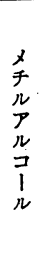 } & & & & $1.113 \times 10^{-1}$ & $5.438 \times 10^{4}$ \\
\hline & 1.250 & $4.850 \times 10^{-2}$ & $3.880 \times 10^{-2}$ & $2.011 \times 10^{-1}$ & $3.333 \times 10^{4}$ \\
\hline & 1.875 & $6.842 \times 10^{-2}$ & $3.649 \times 10^{-2}$ & $2.837 \times 10^{-1}$ & $2.512 \times 10^{4}$ \\
\hline & 2.500 & $8.986 \times 10^{-2}$ & $3.594 \times 10^{-2}$ & $3.726 \times 10^{-1}$ & $1.942 \times 10^{4}$ \\
\hline & 3.125 & $1.213 \times 10^{-1}$ & $3.880 \times 10^{-2}$ & $5.027 \times 10^{-1}$ & $1.333 \times 10^{4}$ \\
\hline & 3.750 & $1.348 \times 10^{-1}$ & $3.594 \times 10^{-2}$ & $5.588 \times 10^{-1}$ & $1.294 \times 10^{4}$ \\
\hline & 4.375 & $1.575 \times 10^{-1}$ & $3.601 \times 10^{-2}$ & $6.531 \times 10^{-1}$ & $1.106 \times 10^{4}$ \\
\hline & 6.563 & $2.181 \times 10^{-1}$ & $3.247 \times 10^{-2}$ & $8.834 \times 10^{-1}$ & $9.067 \times 10^{3}$ \\
\hline & & $2.544 \times 10^{-2}$ & $4.070 \times 10^{-2}$ & $1.032 \times 10^{-1}$ & $6.057 \times 10^{4}$ \\
\hline & 1.250 & $4.406 \times 10^{-2}$ & $3.525 \times 10^{-2}$ & $1.788 \times 10^{-1}$ & $4.039 \times 10^{4}$ \\
\hline & 1.875 & $6.409 \times 10^{-2}$ & $3.418 \times 10^{-2}$ & $2.601 \times 10^{-1}$ & $2.863 \times 10^{4}$ \\
\hline ン & 2.500 & $8.445 \times 10^{-2}$ & $3.378 \times 10^{-2}$ & $3.427 \times 10^{-1}$ & $2.199 \times 10^{4}$ \\
\hline \multirow[t]{2}{*}{ ぜ } & 3.125 & $1.172 \times 10^{-1}$ & $3.751 \times 10^{-2}$ & $4.757 \times 10^{-1}$ & $1.426 \times 10^{4}$ \\
\hline & 3.750 & $1.309 \times 10^{-1}$ & $3.491 \times 10^{-2}$ & $5.312 \times 10^{-1}$ & $1.373 \times 10^{4}$ \\
\hline & 4.375 & $1.536 \times 10^{-1}$ & $3.512 \times 10^{-2}$ & $6.234 \times 10^{-1}$ & $1.163 \times 10^{4}$ \\
\hline & 6.563 & $2.079 \times 10^{-1}$ & $3.167 \times 10^{-2}$ & $8.435 \times 10^{-1}$ & $9.526 \times 10^{3}$ \\
\hline
\end{tabular}

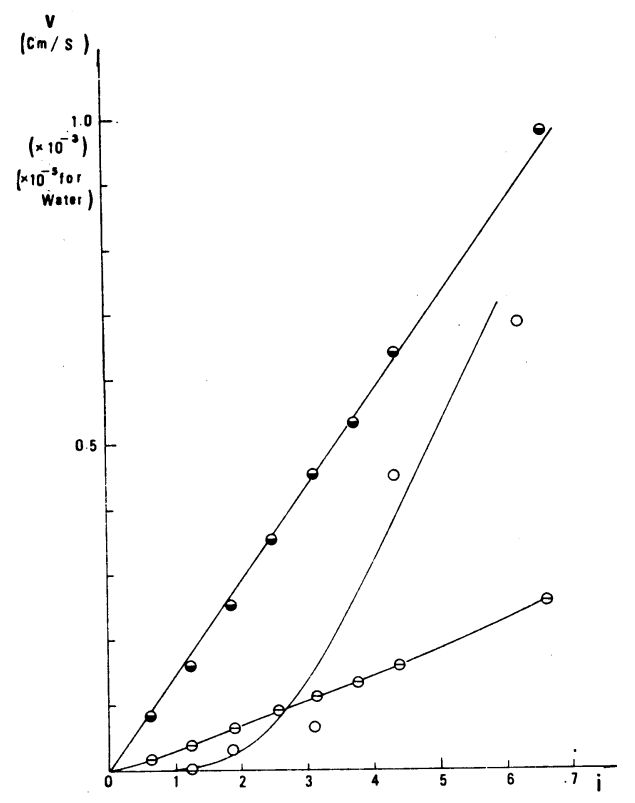

図一7粘土の $v \sim i$ 间係

$$
\begin{aligned}
& R_{e}=\frac{v \cdot d_{m}}{\nu} \\
& i=\frac{\zeta}{d_{m}} \frac{v^{2}}{2 g}
\end{aligned}
$$

で計算されている。ここで, $\nu$ : 流体の動粘性係数, $d_{m}$ : 平均粒径である。さらに, これらの計算に必要な流体, 多孔体特性值は表一1 に揭げたものを用いた。粘土, シ

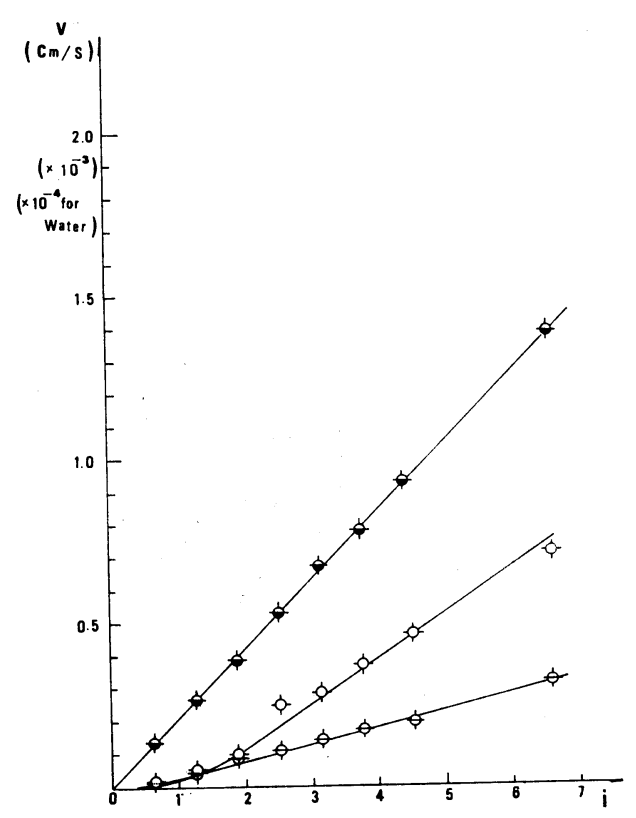

図一8 シルト撗粘土の $v \sim i$ 関保

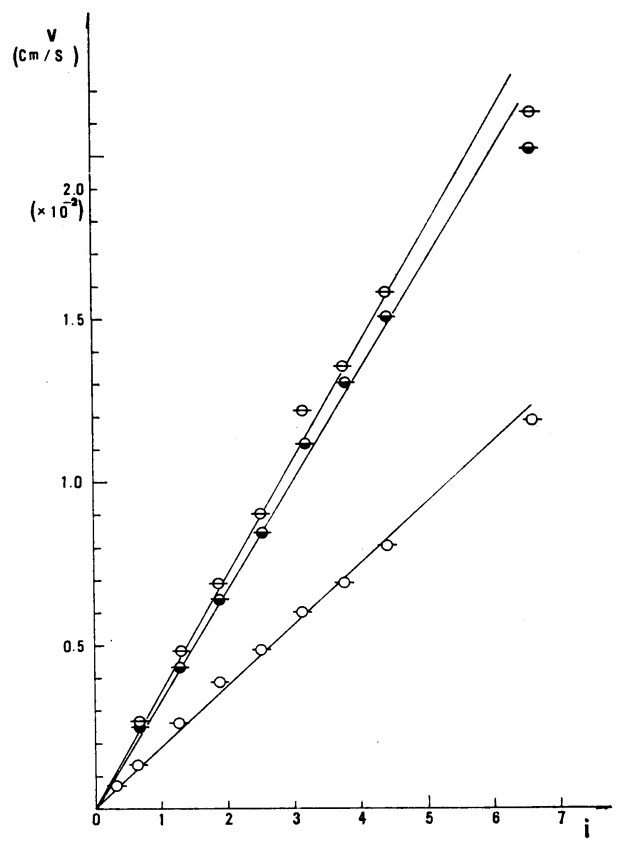

図一9 細砂の $v \sim i$ 间係

ルト質粘土, 細砂の $v \sim i$ 関係を水, メチルアルコール, ベンゼンについてプロットしたものが，図一7，8，9 で ある (図中の記号は図一10 に対応する)。図一7,8 中， 水による $v$ はプロットの都合上，それぞれ，10 $10^{-5}, 10^{-4}$ 乗である。

水による $v \sim i$ 関係は粘土, シルト質粘土の場合とも に吸着効果による非線型性が明確であり, 始動動水勾配 


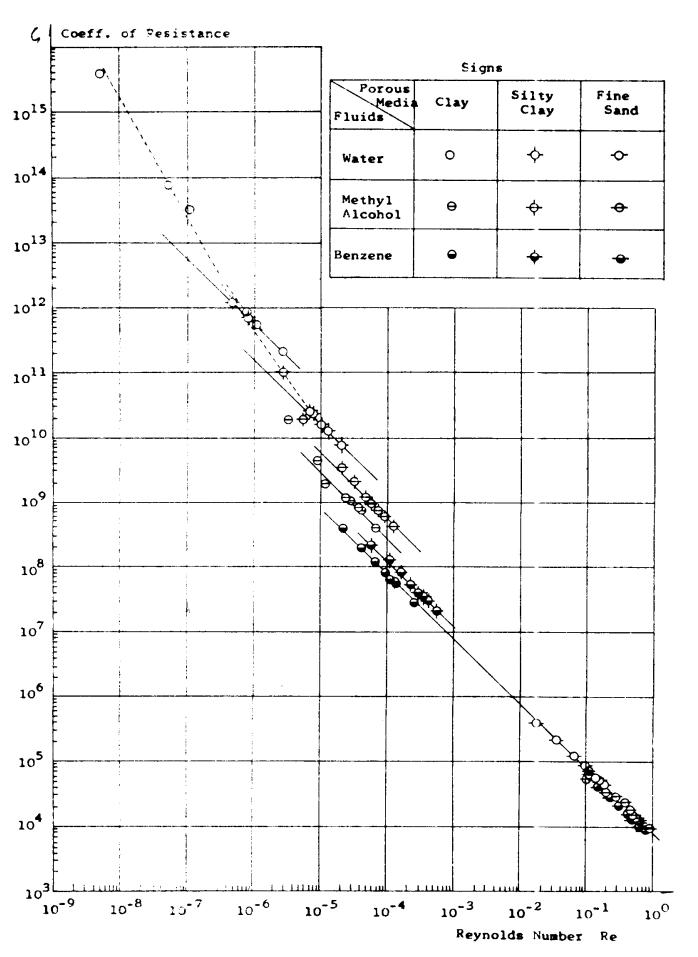

図一10抵抗係数とレイノルズ数の関係

も認められる。

しかし、メチルアルコールの場合, 吸着効果は弱いた め, ほぼ $v \sim i$ 関係は線型的である。ベンゼンの場合, 吸着効果がないためダルシー則がそのまま成立する。

他方, 細砂の $v \sim i$ 関係は水, メチルアルコール, ベ ンゼンともにダルシー則を満たしている。

つまり, 水, メチルアルコールの場合でも, 細砂のよ らに空げき規模が微粒土に比べ大きいとき, 吸着効果は 顕著でないことがわかる。

これらの結果は抵抗係数とレイノルズ数で整理すれ ば，図一10の上うになり，吸着効果による流場内の粘 性の見掛け上の増加, いいかえれば, 抵抗係数の増加を 的確に知ることができよう。

\section{6. 検討}

実測結果をもとに $v \sim i$ 関係, $\zeta \sim R_{e}$ 関係, 流場内の 平均粘性係数, 平均吸着水層の厚さについて考える。

\section{(1) $v \sim i$ 関係}

粘土, シルト質粘土の場合の透水実験から, $v \sim i$ 関 係に注目する。

1.で述べたように, v〜i 関倸の従来の実測結果には 三通りのタイプが観測されているが，筆者らの実験では 図一1の（c）の形である。つまり, 粘土, シルト質粘 土の二者の結果ともに始動動水勾配が存在し, $v \sim i$ 関 係は $i$ の増加にともない非線型的に変化している。

微速浸透流のメカニズムについて前述したように粘土 では $i_{n}=3$ 程度, シルト質粘土では $i_{n}=2$ 程度を限界 值として, $i_{n}>i$ で $v \sim i$ 関係はレオロジー的変化を, $i_{n}<i$ でダルシ一則を満たす, いわゆるニュートン流動 的変化を示すことがわかる。要するに, 微速浸透流はレ オロジ一的特性と流体力学的特性をあわせもつことが実 測結果から認められる。

次に, $\sim i$ 関係の定式化であるが, これら実測では Buckingham-Reiner の式, Swartzendruber の経験式 がそれぞれの式に含まれる定数を適当に決めれば，成立 するものと考えられる。

\section{(2) 抵抗係数とレイノルズ数の関係}

抵抗係数とレイノルズ数の関係は, 通常水の吸着効果 が流れに大きな影響を与えない場合，

$$
\zeta R_{e}=a
$$

であることが知られている。ここで, $a$ は多孔体の幾何 的形状にのみ関係する定数である。

しかし, 図一10 からわかるように粘土, シルト質粘 土の実測結果は前者の場合, $R_{e}=10^{-6}$ 程度, 後者は $R_{e}$ $=10^{-5}$ 程度から, 式 (6) の関係に従わない $R_{e}$ がある。

このことを明確に知るため, 粘土, シルト質粘土によ る水, ベンゼンの実測結果を $\zeta R_{e} \sim R_{e}$ 関係でプロット したものが 図一11 である。図から，ベンゼンの場合は 吸着効果がないから式 (6) は成立するが, 水の場合は 吸着効果のため, 単純に式 (6) が成立しない。ここで, 特に注目したいのは, 同一の粘土, シルト質粘土で空げ き率が同一であるにもかかわらず (表一1 参照), 式 (6) の $a$ の值が水とベンゼンの場合に大きく違っているこ とである。これが後述する流場内の平均粘性係数の見掛

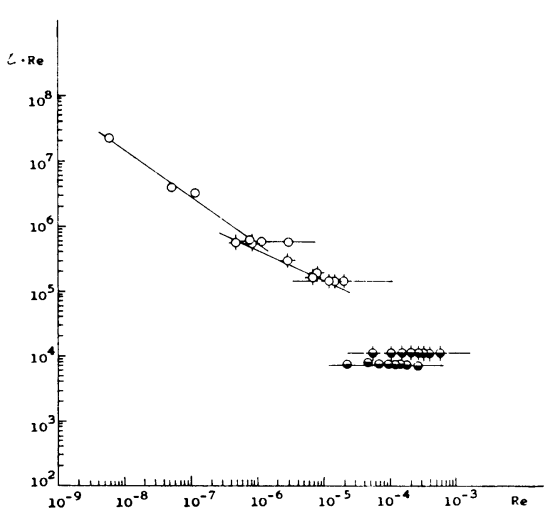

図一11 $\zeta \boldsymbol{R}_{e} \sim \boldsymbol{R}_{e}$ 関係 
け上の增大であることはいうまでもない。

いま, 図一11 を参照して, $\zeta R_{e} \sim R_{e}$ 関係を

$$
\zeta R_{e}=a \cdot b \cdot \frac{c}{R_{e}{ }^{k}}
$$

と仮定する。ここで, $\kappa$ : 指数, $a$ : 多孔体の幾何的形状 のみに関係する定数, $b$ : 吸着効果のみに起因する定数, さらに $c:$ 多孔体の幾何的形状と吸着効果の両者に関係 する定数であると考える。

そうすれば, 式 (7) の両辺の対数をとり,

$\log _{10}\left(\zeta R_{e}\right)=\log _{10} a+\log _{10} b+\log _{10} c$ $-\kappa \log _{10} R_{e}$

と書き, 水による粘土, シルト質粘土の $a, b, c, \kappa$ の值 をそれぞれ実測值から決定できる。

まず粘土の場合, 式 (8) の $a$ の值は図一11 の粘土 のベンゼンによる $\zeta R_{e} \sim R_{e}$ 実測值の平均から, $a=$ $7.135 \times 10^{3}$ 上なり, また, 粘土の水による值 $5.718 \times$ $10^{5}$ から， $b=5.718 \times 10^{5} / 7.135 \times 10^{3}=8.014 \times 10$ であ る。さらに, 定数 $c$, 指数 $\kappa$ の決定は $\zeta R_{e}, R_{e}$ の任意 の二つの值, $\zeta R_{e}=5.718 \times 10^{5}, R_{e}=9.0 \times 10^{-7}$, また, $\zeta R_{e}=7.0 \times 10^{6}, R_{e}=3.0 \times 10^{-8}$ を $a, b$ の值とあわせ 式 (8) 人代入することによってなされる。計算の結果, $c=3.527 \times 10^{-5}, \kappa=0.736$ となり, $\zeta \sim R_{e}$ 関係は

$$
\zeta=7.135 \times 10^{3} \cdot 8.014 \times 10 \cdot \frac{3.527 \times 10^{-5}}{R_{e}^{1.736}} \cdots
$$

あるいは,

$$
\zeta=\frac{2.016 \times 10}{R_{e}^{1.736}}
$$

となる。

次に, シルト質粘土の場合も同様に図一11 から， $a=$ $1.133 \times 10^{4}$, また $b=1.362 \times 10$ となり, $\kappa, c$ は $\zeta R_{e}=$ $1.543 \times 10^{5}, \quad R_{e}=10^{-5}, \zeta R_{e}=9,0 \times 10^{5}, \quad R_{e}=2 \times 10^{-7}$, さらに, $a, b$ の值を用いて $, \kappa=0.451, c=5.560 \times 10^{-3}$ となる。

したがって,ら〜 $R_{e}$ 関係は

$$
\zeta=1.133 \times 10^{4} \cdot 1.362 \times 10 \cdot \frac{5.560 \times 10^{-3}}{R_{e}^{1.451}} \cdots
$$

あるいは,

$$
\zeta=\frac{8.580 \times 10^{2}}{R_{e}^{1.451}}
$$

となる。

以上の計算から，抵抗係数とレイノルズ数の関係はも し流れにおいて吸着効果が存在しなければ， $b, c$ はとも に 1 と考え, $\kappa=0$ とすれば, 従来用いられている, $\zeta R_{e}$ $=a$ の関係が成立する。しかし，実際の微速浸透流では 吸着効果に関係する定数 $b, c, \kappa$ が重要な影響をもち, 別の立場からすれば, 式 $(9)^{\prime},(10)^{\prime}$ は吸着効果を含 み，低レイノルズ数浸透流では単に $\zeta R_{e}=a$ の関係が 成立しないことを示している。
なお, 図一10 に実測值から求めた式 $(9)^{\prime},(10)^{\prime}$ の関 係を点線で示しておいた。

\section{（3）平均吸着水層の厚さと平均粘性係数}

すでに，図一6 で説明したように，微粒土内の水分子 密度, 粘性係数が見脚け上増大し, それによって浸透流 は著しい影響を受けている。これは $v \sim i$ 関係, $\zeta \sim R_{e}$ 関係の実測結果からただちにわかる。

ここで，不規則な微粒土内の空げきをかりに，等価な 球粒子の集合体内の空げきで置き換え, 平均吸着水層の 厚さを推定する。さらに，吸着効果による見掛け上の平 均粘性係数を見積ることを試みる。

水の浸透係数 $k$ を推定する公式は多く提唱されてい るが，その一つに, Rose-Fair-Hatch の式がある。

$$
k=\frac{C}{\nu} \lambda^{4} d_{s}{ }^{2}
$$

ここで, $レ$ : 水の動粘性係数, $\lambda$ : 空げき率, $d_{s}$ : ある 代表的粒径, $C$ : 多孔体の粒形特性のみから決まる定数 である。

式（11）は，ろ過砂のような比較的粒径のそろった砂 に対して得られたものだが，もし水の吸着効果がなけれ ば，無論粘土にも適用できるはずである。しかし，微粒 土の場合, 単に吸着効果のみのため, 実際上, 適用でき ないと考える。そこで, この吸着効果を流場内の空げき 率の見掛け上の減少といら観点から捉えれば，ある粒径 $d_{s}$ を平均粒径 $d_{m}$ にとり, 形式上

$$
\begin{aligned}
k_{w} & =\frac{C}{\nu_{w}} \lambda_{w}{ }^{4} d_{m}{ }^{2} \\
k_{b} & =\frac{C}{\nu_{b}} \lambda_{b}{ }^{4} d_{m}{ }^{2}
\end{aligned}
$$

と書くことができる。ただし， $k, \nu, \lambda$ の添字 $w, b$ はそ れぞれ，水，ベンゼンによるものを示す。

式 (12), (13) 中の定数 $C$ は水, ベンゼンによる実 験において, 上試料の粒形特性が両者ともに等しいか ら，同一值をとると考えられる。そこで，二式から $C$ を消去すれば，

$$
\frac{\lambda_{w}}{\lambda_{b}}=\left(\frac{k_{w}}{k_{b}} \cdot \frac{\nu_{w}}{\nu_{b}}\right)^{1 / 4}
$$

となる。

次に, 図一12 を参照し, ある体積の土試料中の微粒 土の空げき率に等しい球粒子 の集合体を想定する。そこ で, 水の場合, 平均吸着水層 の厚さ $t$ を導人すれば, 空げ き率 $\lambda_{w}$ は

$$
\lambda_{w}=1-\frac{\pi N}{6 V}\left(d_{m}+2 t\right)^{3}
$$

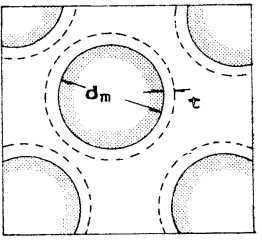

図-12 平均吸着水屈 のモデル 
であり, 他方, ベンゼンの場合, 吸着効果がないから,

$$
\lambda_{b}=1-\frac{\pi N}{6 V} d_{m}{ }^{3}
$$

である。ここで， $N$ : 球粒子の数， $V$ : 土試料の体積， $t:$ 平均吸着水層の厚さである。

通常, 平均吸着水層が存在すれば, 見掛け上，流れに 関与する空げき率は減少するから， $\lambda_{b}>\lambda_{w}$ である。

式 (16) 加式 (15) を減じ, $r_{n}=\frac{\pi}{6 V} d_{m}{ }^{3} \gamma_{i} N$ を考 慮すれば,

$$
\begin{aligned}
& \lambda_{b}-\lambda_{w}=\frac{r_{n}}{\gamma_{i}}\left\{\left(1+\frac{2 t}{d_{m}}\right)^{3}-1\right\} \\
& \doteqdot 6 \frac{t}{d_{m}} \frac{r_{n}}{r_{i}}
\end{aligned}
$$

が成立する。ここで, $\gamma_{n}$ : 土試料の単位体積重量, $r_{i}$ : 土粒子の真の単位重量である。

したがって，式 (14) を用いて, $k_{w}, k_{b}, \nu_{w}, \nu_{b}, \lambda_{b}$ が 実測されているから， $\lambda_{w}$ を決定でき, 式 (17) から, 平均吸着水層の厚さ $t$ を推定することができる。

粘土の場合の $t$ は次のように求をる。

表一1 から， $\nu_{w}=0.0127 \mathrm{~cm}^{2} / \mathrm{sec}, \nu_{a}=0.0078 \mathrm{~cm}^{2} / \mathrm{sec}$, $\lambda_{b}=0.462, d_{m}=0.002 \mathrm{~cm}, r_{i}=2.63 \mathrm{~g} / \mathrm{cm}^{3}$, さらに, 表 -2 加ら， $k_{b}$ は平均的に, $k_{b}=1.399 \times 10^{-4} \mathrm{~cm} / \mathrm{sec}$, ま た， $k_{w}$ は $v \sim i$ 関係が線型的変化をする透水係数を平 均して, $k_{w}=1.090 \times 10^{-6} \mathrm{~cm} / \mathrm{sec}$ である。なお， $r_{n}$ は $\lambda_{b}$ と $r_{i}$ 加簡単に求まり, $1.415 \mathrm{~g} / \mathrm{cm}^{3}$ となる。

それぞれの值を式 (14)，(17）に代入し，

$$
\begin{aligned}
\lambda_{w} & =0.462\left(\frac{10.90 \times 10^{-7}}{1.399 \times 10^{-4}} \cdot \frac{0.0127}{0.0078}\right)^{1 / 4} \\
& \doteqdot 0.156 \\
t & =\frac{1}{6} \frac{2.630}{1.415} 0.002(0.462-0.156) \\
& \doteqdot 1.898 \text { ミクロン }
\end{aligned}
$$

同様に, シルト質粘土の場合, $\nu_{w}=0.0112 \mathrm{~cm}^{2} / \mathrm{sec}$, $\nu_{b}=0.0078 \mathrm{~cm}^{2} / \mathrm{sec}, \lambda_{b}=0.443, d_{m}=0.0031 \mathrm{~cm}, r_{i}=$ $2.708 \mathrm{~g} / \mathrm{cm}^{3}$, また, $k_{w}=1.053 \times 10^{-5} \mathrm{~cm} / \mathrm{sec}, k_{b}=2.108$ $\times 10^{-4} \mathrm{~cm} / \mathrm{sec}, \gamma_{n}=1.511 \mathrm{~g} / \mathrm{cm}^{3}$ を式 (14)，(17）に代 入し,

$$
\begin{aligned}
\lambda_{w} & =0.443\left(\frac{1.053 \times 10^{-5}}{2.108 \times 10^{-4}} \frac{0.0112}{0.0078}\right)^{1 / 4} \\
& \doteqdot 0.229 \\
t & =\frac{1}{6} \frac{2.708}{1.511} 0.0031(0.443-0.229) \\
& \doteqdot 1.980 \text { ミクロン }
\end{aligned}
$$

となる。

この方法で得られた $t$ は, 吸着効果によって実質上, 空げき率が減少するという立場から，評価されなければ ならない。

次に, 平均粘性係数を次のように見積る。式 (14) か
ら,

$$
\frac{k_{w}}{k_{b}} \cdot \alpha \frac{\mu_{w} / \rho_{w}}{\mu_{b} / \rho_{b}}=\left(\frac{\lambda_{w}}{\lambda_{b}}\right)^{4}=1
$$

と書ける。ここで, $\rho_{w}, \rho_{b}$ :それぞれ，水，ベンゼンの 密度, $\alpha$ : 吸着効果による係数である。

そこで，式（18）を用いて，

$$
\alpha=\frac{k_{b}}{k_{w}} \frac{\nu_{b}}{\nu_{w}} .
$$

が成立する。

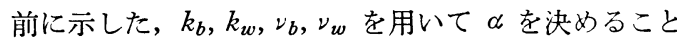
ができる。

粘土の場合, $\alpha$ は

$$
\alpha=\frac{1.399 \times 10^{-4}}{1.090 \times 10^{-6}} \frac{0.0078}{0.0127} \fallingdotseq 78.832
$$

また, シルト質粘土の場合， $\alpha$ は

$$
\alpha=\frac{2.108 \times 10^{-4}}{1.053 \times 10^{-5}} \frac{0.0078}{0.0112} \fallingdotseq 13.941
$$

すなわち，吸着効果を見掛け上の粘性の増加と見れ ば, 粘性係数は, 粘土の場合, 通常の水のそれの約 80 倍, シルト質粘土の場合, 約 14 倍増大したものと考え られる。

\section{7. 結論}

微速浸透流はその抵抗則, 浸透機構にまだ瞹昧な点が 少なくない。その一つの理由に, 現象がミクロ的であ り, 流れを水分子の立場で論じなければならないことが ある。したがって, 実験的に研究する場合, 詳細な注意 を要し, その結果を物性論的に的確に理解することが要 求される。

この研究では, 微速浸透流の特異性をすべて, 水分子 の微粒子表面への吸着効果といら観点で行なわれた。そ のため, 極性分子からなる水と無極性分子からなるベン ゼン，さらに，弱い極性をもつメチルアルコールで浸透 実験を行ない, その結果を比較検討した。

その結果を要約すれば，次のような結論が得られる。

（1）水，メチルアルコール，ベンゼンによる微粒土 の浸透実験で, 各流体による吸着現象の強弱を的確に知 ることができる。

（2）微粒土の透水実験で始動動水勾配が観測され, $v \sim i$ 関係は $i$ が小さい場合, 非ニュートン流動的性質 を示し, $i$ が大きくなるにつれ,ニュートン流動に変わ る。

（3） $v \sim i$ 関係は, Buckingham-Reiner の式, Swartzendruber の経験式のいずれをも満たす。

(4) 微速浸透流の特異性は $\zeta-R_{e}$ 関係によってうま く説明され，式（7）が成立する。

（5）流場内の吸着効果は土粒表面の平均吸着水層の 
存在, あるいは平均粘性係数の見掛け上の増大といら概 念によって簡単に扱うことができる。前者の立場をとれ ば, $t=1.8$ ミクロン程度であり, 後者の立場をとれば, $\alpha=10 \sim 10^{2}$ 程度であると考えられる。

\section{8. あとがき}

筆者らは微粒土中の浸透流の特異性をまったく水分子 の土粒表面への吸着であると断定して, 研究を進めた。 しかしながら，微粒土中の水はそれ自体ミクロに観察す れば，化学的にも物理的にも非常にやっかいなものと考

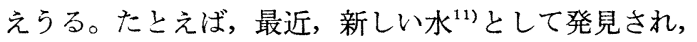
注目されている“super water”あるいは“polywater” に着目しても，その一端はうかがえる。この新しい水は 数十ミクロンの石英, あるいはガラスの細管の中で容易 に形成され, 物理特性 (密度 $1.01 \sim 1.4 \mathrm{~g} / \mathrm{cm}^{3}$, 粘性, 通常の水の約 15 倍) が通常の水と異なっている。

このことから，筆者らが吸着水と呼んでいる水がこの 新しい水である可能性が粘土の鈗物成分からみて皆無と はいえない。

もし，吸着効果の中にこの新しい水が存在するとすれ
ば，別の立場から微速浸透流を考える必要があろう。

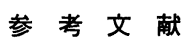

1) King, F.H. : Principles and Conditions of the Movement of Ground Water, U.S. Geol. Survey, the 19 th Ann. Rept., Part 2, pp. 59 294, 1898.

2) Hansbo, S. : Consolidation of Clay, with Special Reference to Influence of Vertical Sand Drains, Swed. Geotech. Inst., Proc. No. 18, Stockholm, pp. $41 \sim 62$, 1960.

3) Kutilek, M. : Temperature and Non-Darcian Flow of Water, Internat. Soil Water Symp., Praha, pp. 44 48, 1967.

4) Swartzendruber, D. : Modification of Darcy's Law for the Flow of Water in Soils, Soil Science, Vol. 93, p. 23, 1961.

5) Swartzendruber : Non-Darcy Flow Behavior in LiquidSaturated Porous Media, J. Geophy. Res., Vol. 67, No. 7, p. 5207, 1962.

6) Hansbo, S. : 前出

7）佐藤：低レイノルズ数浸透流における吸着水の影響につ いて, 土木学会論文報告集, 187 号, pp. $67 \sim 77,1971$.

8）崎川：物性論, 共立出版, p. 33, S. 43.

9) 佐藤 : 前出

10）春日屋編：水工学便覧，森北出版，pp. $2 \sim 7$.

11）伊藤：科学, Vol. 39 , No. 12 , p. 653 .

(1971.5.24 - 受付) 